\title{
Selected Reference Books of 1962-1963
}

\author{
By EUGENE P. SHEEHY
}

\section{INTRODUCTION}

THIS ARTICLE continues the semiannual series $^{1}$ originally edited by Constance M. Winchell. Though it appears under a byline the list is actually a project of the reference department of the Columbia University libraries, and notes are signed with the initials of individual staff members. $^{2}$

Since the purpose of the list is to present a selection of recent scholarly and foreign works of interest to reference workers in university libraries it does not pretend to be either well balanced or comprehensive. Code numbers (such as A11, 1A26, 2S22) have been used to refer to titles in the Guide ${ }^{3}$ and its supplements.

\section{GuIDES}

Maichel, Karol. Guide to Russian Reference Books. Edited by J. S. G. Simmons. Stanford, Calif.: Hoover Institution, 1962v.1- . (Stanford University. Hoover Institution on War, Revolution and Peace. Bibliographical ser., no.10) v.1, $\$ 5$.

This first volume brings together from Russian and other sources 379 items of general bibliography and related reference materials, arranged and annotated as a guide, with broad chronological coverage. Subject bibliography is reserved for sections to be published later. Although generally well edited, there are errors such as the omission of title page information, failure to cite

\footnotetext{
${ }^{1}$ CRL, January and July issues starting January 1952.

2 Evelyn Allen, Eizenija Bergman, Eleanor Buist, Rita Keckeissen, Elizabeth J. Rumies, Susan Thompson, John Neal Waddell.

3 Constance M. Winchell, Guide to Reference Books (7th ed.; Chicago: ALA, 1951) : Supplement (Chicago: ALA, 1954); Second Supplement (Chicago: ALA, 1956); Third Supplement (Chicago: ALA, 1960 ) ; Fourth Supplement (Chicago: ALA, 1963).
}

Mr. Sheehy is a member of the reference staff of the Columbia University libraries.

latest edition, incorrect periodicity, etc. Because the work will be valuable to larger libraries and to specialists, it is hoped that editorial standards can be maintained and, where needed, improved.-E.B.

Malclès, Louise-Noëlle. Manuel de bibliographie. Paris: Presses Universitaires de France, 1963. 328p. 32 fr.

A new work, not merely a new edition of the author's Cours de bibliographie .... , 1954 (Supplement 2A4), this will nonetheless largely supplant the earlier title. In approach it is less specifically designed as a textbook than its predecessor, but the content is of the same general nature, although considerably rearranged. Titles and editions appearing since 1954 are, of course, duly noted, as applicable. Thus the work can serve as an updated abridgement of the author's four-volume major work, Les sources du travail bibliographique (Supplement 1A101, etc.) for the small library or the individual not needing, or not prepared to pay for the larger set.-J.N.W.

Musiker, Reuben. Guide to South African Reference Books. 3d rev. ed. Grahamstown: Rhodes University Library, 1963. 161l. mimeographed. Rl.25.

Earlier editions of this annotated bibliography, patterned on Winchell's Guide, were not widely distributed. This new revision lists five hundred of "the more important reference books on South African topics" (Introd.) published, with few exceptions, in the Republic of South Africa. Most are English language books, for the work does not pretend to comprehensiveness for 
Afrikaans sources. Where no standard reference work for a South African subject exists, general books of the handbook type have been substituted. Materials are arranged in nineteen wide subject categories according to Dewey classes with appropriate subdivisions. Within each section, works are listed alphabetically by author. Entries are numbered serially throughout. An index of authors, titles and some subjects is appended.-R.K.

\section{Neiswender, Rosemary. Guide to Russian Reference and Language Aids. New York: Special Libraries Association, 1962. 92p. (S.L.A. Bibliography, no.4) $\$ 4$.}

There are 221 well-annotated entries for works of reference in this practical manual which emphasizes publications since World War II. The listing and evaluation of 87 language textbooks and readers, as well as language records, is a unique feature. Other chapters include dictionaries and glossaries, encyclopedias, geographical reference works, bibliographies, indexes, translation digests and current biographical aids. Appendixes contain a comparative table of seven transliteration systems, a list of retail sources of Russian publications, and a glossary of Russian bibliographic and book trade terminology. The work will be useful in a wide range of libraries and to many individual students and research workers utilizing Russian materials in any field.-E.B.

\section{BIBLIOGRAPHY}

Ferguson, John Alexander. Bibliography of Australia. Sydney and London: Angus and Robertson, 1941- . v.1-

Contents: v.5, 1851-1900, A-G. 1146p.

Although this volume represents a continuation of an established bibliography (Guide V153, Supplement 1V35), the changes in scope and arrangement make a note on this new phase desirable. The earlier volumes attempted to include all printed matter relating to Australia, wherever published, for the period 1784-1850; the volumes for 1851-1900 will be devoted to printed books, pamphlets, and broadsides, with several important categories excluded, e.g., belles-lettres covered by the Miller and
Macartney bibliographies (Guide R254, Supplement 3R49), parliamentary and other government papers, periodicals, elementary school books, and technical treatises. The chronological arrangement of the earlier volumes has been abandoned in favor of an alphabetical listing by main entry; locations in selected libraries continue to be included. Two further volumes are scheduled, the final one (v.7 of the set) to include a subject index and addenda.-E.S.

\section{LIBRARIES}

Collins, Robert and Duignan, Peter. Americans in Africa; a Preliminary Guide to American Missionary Archives and $\mathrm{Li}$ brary Manuscript Collections on Africa. Stanford, Calif.: Hoover Institution, 1963. 96p. (Stanford Univ. Hoover Institution on War, Revolution and Peace. Bibliographical ser., no.12) \$2.

The editors stress that this is only a preliminary survey of United States library resources on American activity in Africa. As such the information is not exhaustive, but serves merely to point out possibly useful collections. The guide is in two principal parts, "Missionary Archives" and "Library Manuscript Collections," each listing institutions and briefly describing their holdings. There are two appendices, one giving the names of "American Missionary Sending Societies" grouped by religious denomination, the other providing a geographical grouping of the archives according to the African area served.-E.A.

Directory of Special Libraries and Information Centers. Anthony T. Kruzas, ed. Detroit: Gale Research Co., 1963. 767p. $\$ 25$.

In this alphabetic listing of ten thousand United States and Canadian institutions, there is given for each the address, telephone, staff, subjects covered, holdings, services, publications, etc. There are nine appendixes of types of libraries (e.g., United States regional libraries for the blind; libraries with United States patent files) and a subject index. Format resembles that of the publisher's Encyclopedia of American Associations (Supplement 3C4) and is easy to use, but the volume is considerably bulkier and 
more expensive than Ash, Subject Collections (Supplement 3B13); this somewhat overlaps the latter but does not duplicate it, includes many libraries not in Ash (and vice versa), and is, of course, more recent. -E.J.R.

U.S. Library of Congress. African Section. African Libraries, Book Production, and Archives; a List of References. Compiled by Helen F. Conover. Washington: 1962. 64p. 60c.

Everything African being of paramount interest at present, this publication is a welcome one. It is a selective index of 341 items, which aims to provide a basic reading list for the three topics mentioned in the title. They are given separate treatment, with regional breakdowns for the first and third. Emphasis is on newly emerging Afri$\mathrm{ca}$, the white South and the Arab North being largely excluded. Bibliographical citations are complete; library locations are indicated; and there are many useful annotations. There is an author index, but none by subject. This should prove valuable to virtually all libraries and many other organizations concerned with Africa.-S.T.

\section{ENCLYCLOPEDIA}

The Columbia Encyclopedia. 3d ed., edited by William Bridgwater and Seymour Kurtz. New York: Columbia University Press, 1963. 2388p. \$49.50.

For second ed., 1950 and its illustrated supplement, 1956, see Guide D7 and Supplement 3D1.

In the present work the editors have wisely chosen to maintain the same general scope and treatment established in the earlier editions, widely esteemed by librarians and laymen. All articles from the last edition have been examined for possible revision, and spot checking indicates that a large percentage of those not needing major changes have received suitable minor revisions in text and in bibliography. The real reason for the new edition is, however, not the need for such routine editing, but the inclusion of new articles and the insertion of major changes and updated information to incorporate the significant events of the past thirteen years. Again, the work seems well done, especially so in political and social affairs. Inevitably, the inclusion of a large number of biographical sketches of living persons offers problems of selection and relative importance, and although it is easy to question many individual choices, the over-all judgment seems sound. The black and white illustrations first appearing in the 1956 supplement are presumably now a permanent feature, as are a number of newly introduced maps.-J.N.W.

\section{PERIODICAL INDEX}

British Humanities Index. Annual cumulation v.1- . 1962- . London: Library Association, 1963.

With the appearance of the first annual cumulation of this title, it is a pleasure to call attention to a feature not included in the quarterly issues of the index, and not anticipated in an earlier (January 1963) note in these pages. The second part of the cumulated volume is designated "Author Section," and provides an author approach (with full citations) to the signed articles. This will prove a welcome aid in various kinds of bibliographic searching.-E.S.

\section{DIRECTORY}

Trade Associations and Professional Bodies of the United Kingdom; a Directory and Classified Index. Compiled by Patricia Millard. London: C.B.D. Research Ltd., 1962. 128p. 30s.

This list of almost nineteen hundred national associations of the United Kingdom is designed "to provide a ready means of finding the address and telephone number" of such organizations and "to identify the associations concerned with any specific field of activity" (Introd.). Part I is an alphabetical listing of associations with address and telephone number; Part II is a classified index. Although the introduction states that "explanatory notes ... had to be limited to the briefest minimum" in this first edition, no annotations at all appear. Future editions are planned.-R.K.

\section{GOVERNMENT DOCUMENTS}

Vogel, Robert. A Breviate of British Diplomatic Blue Books, 1919-1939. Montreal: McGill University Press, 1963. 474p. $\$ 10.50$.

Planned as a continuation of Temperley and Penson's useful Century of Diplomatic 
Blue Books, 1814-1914 (1938), the present work includes some eighteen hundred items in a chronological listing. Arrangement within each year or session is categorical rather than topical (i.e., bills, general sessional papers, and command papers), so that the detailed index must be used for any kind of subject searching. For each item, bibliographic information includes full title, volume number in the collected set of parliamentary papers (and beginning page, applicable only in Parliament's own set), command number if any, and exact date of presentation. In addition to purely diplomatic items, there is a generous inclusion of domestic papers of potential interest in the study of diplomatic questions. A lengthy preface reviews chronologically the general course of British diplomatic policies throughout the twenty-year period.-J.N.W.

\section{Statistics}

Statistical Sources. Edited by Paul Wasserman [and others ${ }_{\text {] }}$. Detroit: Gale Research Co., ${ }_{[1962}$ ]. 288p. \$15.

Under alphabetic subject headings ("Abrasives" through "Zoology-Degrees Conferred") are listed sources of current statistical information, usually a publication but occasionally an organization or agency where no specific publication is available. The United States government is, understandably, predominant here but the occasional citing of other sources and the efficient arrangement make the work a useful adjunct to the Monthly Catalog and the Statistical Abstract.-E.J.R.

\section{Political Science}

Bildungswerk Europäische Politik. Bibliographie zur europäischen Integration. [Düsseldorf $]$ : Europa-Union Verlag, 1962. 180p. DM. 9,80 .

This is a compact listing of some six hundred basic German and French (with some English and Italian) books. Its main sections are devoted to selected titles on various aspects of European integration: the organizations developed; the relations of these organizations among themselves and with NATO, East Europe, and Africa; and the problems and achievements of European economic integration attempts. A first section lists titles on the theory and the legal, social, and political background of international organizations. The last section cites bibliographies, yearbooks, handbooks, serial publications of the organizations, and journals regularly publishing articles on European unity. Each entry, annotated in German, gives full imprint and pagination. There is an author index.-E.J.R.

\section{Education}

Drouin, Edmond G. The School Question: a Bibliography on Church-State Relationships in American Education, 1940-1960. Washington: Catholic University Press, 1963. 261p. \$7.50.

Public aid to church-related schools, released time, Bible reading and the wearing of religious garb in public schools are among the many aspects of the "school question" considered in this bibliography. Some thirteen hundred items (books, periodical articles, graduate theses, and court decisions) are listed in a classified arrangement, with an index of authors, editors, cases, and book titles. Many entries are annotated. The compiler points out that the standard indexes-general, as well as those for religion, law, and education-were systematically searched in an effort to represent "all significant positions" on the question.-E.S.

Guide to American Educational Directories, 1963; a Guide to the Major Educational Directories of the U.S. Prepared by Bernard Klein. New York: B. Klein and Co., 1963. 322p. \$20.

Something of a catch-all, this volume lists thirteen hundred-odd titles, many standard, some not so well known, some of less than "major" importance. The title is too narrow and imprecise: many items are educational only by stretching the term; also, included are not only directories (of federal, state and local agencies and various private organizations) but many bibliographies of services and sources of information. There is comparatively little duplication of the Guide to American Directories (Supplement 4L116). Annotations for each entry set forth scope, arrangement, frequency, price, provenance. Arrangement is by title within rough subject grouping, e.g., Advertising, Camps, Financial Aid, Law, Travel. A very brief section of foreign directories is included.-E.J.R. 


\section{DictionaRIES}

Springhetti, Emilio. Lexicon linguisticae et philologiae. Rome: apud Pontificiam Universitatem Gregorianam, 1962. 687p. (Latinitas perennis VI).

At head of title: Schola Superior Litterarum Latinarum in Pontificia Universitate Gregoriana.

The author of this scholarly glossary of thousands of terms used in linguistics and philology has chosen to write the text of all definitions in Latin, giving in the preface a lengthy explanation of the reasons for his decision, this also in Latin. English, French, German, Spanish, Italian and Latin forms of the words defined are all listed in one alphabet; the actual definition is usually given from the Latin or Italian only, with cross references as needed from the other languages. General and specialized, popular and technical terms are all included, and although there is considerable variation in length and explicitness of the definitions, the relative balance seems well maintained.J.N.W.

U.S. Joint Chiefs of Staff. A Dictionary of United States Military Terms. Washington: Public Affairs Press, 1963. 316p. $\$ 4.50$.

Technical and other terms of special meaning or significance in military affairs are briefly defined in this dictionary, earlier editions of which had been issued as Defense Department publications. Comprehensiveness is not claimed, and special attention is given to words and phrases which have come into wider usage since World War II. Weapons terms are "confined to significant modern weapons" (Foreword). A separate section lists words included in the "NATO Glossary of Military Terms and Definitions" and defines those not included in the main section, or for which the NATO-approved definition differs. There is a combined index for the two sections.E.S.

\section{SCIENCE}

Battelle Memorial Institute, Columbus, Ohio. Guide to the Scientific and Technical Literature of Eastern Europe, prepared for the National Science Foundation . . . October 1962. Washington: 1963 ] 94p. (NSF 62-49).
For Albania, Bulgaria, Czechoslovakia, Hungary, Poland, Rumania and Yugoslavia, the guide "contains information on the announcement, procurement, and translation of East European publications in the physical, biological, and certain of the social sciences" (Introd.). Social sciences represented in the periodicals list are anthropology, archaeology, demography, ethnography, linguistics, statistics, and psychology. Medicine and agriculture are excluded. The work complements a similar guide for Soviet materials (Supplement 4N1).-E.B.

Directory of British Scientists. London: Benn, 1963. 1289p. $£ 66 s$.

Not a "who's who," this alphabetic listing of some thirty thousand British men and women was compiled "on the basic premise of a degree in science from a British university" (Introd.). Excluded from this edition are Commonwealth scientists, engineers, those whose professional qualification is the equivalent of a degree, and those already included in the various directories of their professions. Even so, this volume offers an extensive register of persons actively engaged in or retired from work in various fields of science, including administration. For each name is given such information (supplied by the biographee) as: address, degrees, positions held, memberships, and publications. Useful appendixes include a classification by field, a list of scientific societies and their journals, and a list or research establishments.-E.J.R.

\section{The Harper Encyclopedia of Science. Edited}

by James R. Newman. New York: Harper \& Row, 1963. 4v. 1379p. \$29.95.

Intended for the nonspecialist, this set was planned as a work of moderate length, covering "the whole field of science-the major facts and theories-from astronomy to zoology" (Introd.). As far as possible, "longish integrated articles" have been given preference over mere dictionary-type entries; biographical sketches of leading scientists are included; and there are numerous illustrations. In addition to cross references in the set itself, there is a detailed index. Volumes are paged consecutively; articles are signed with initials; and there is a bibliography in the final volume. Although the needs of the average educated user have 
been the criterion, and while an effort was made to limit the use of jargon, the introduction points out that not every article (e.g., those on highly technical concepts and theories) will be understood by everyone. Even so, for the nonscientist and in the small library unable to afford the larger set, this should fill a need not always met by the McGraw-Hill Encyclopedia of Science and Technology (Supplement 4P20) with its rather more specialized orientation.-E.S.

\section{U.S. Library of Congress. Science and Tech-} nology Division. A Guide to the World's Abstracting and Indexing Services in Science and Technology. Washington: 1963. 183p. (National Federation of Science Abstracting and Indexing Services Report, no.102) $\$ 5$.

This guide, which combines and brings up to date the information in Index Bibliographicus, v.1 (Supplement 4A4) and $A$ Guide to U.S. Indexing and Abstracting Services in Science and Technology (Supplement 4N9), serves as an aid in searching the literature of science and technology, listing the major indexing and abstracting services in these fields currently published throughout the world. Included are serial publications of an association, government agency, library, professional society, or commercial body which contain "abstracts and/ or references to currently published scientific and technical literature in the form of pamphlets, books, patents, technical reports, and related materials" (Introd.). The list (1855 entries from 40 countries) is arranged alphabetically by title, and detailed information is given for each service. Table of contents is arranged by Universal Decimal Classification; country and subject indexes add to the book's usefulness.-R.K.

\section{LITERATURE}

Grigson, Geoffrey. The Concise Encyclopedia of Modern World Literature. New York: Hawthorn, [1963]. 512p. \$15.

Spender, Stephen and Hall, David. The Concise Encyclopedia of English and American Poets and Poetry. New York: Hawthorn, $[1963$ ] 415 p. \$15.

These are, in a sense, companion volumes (with some overlapping) boasting good format, numerous high-quality illustrations, and lists of distinguished contributors. Both run heavily to author entries, the articles being critical and evaluative with a minimum of biographical detail.

The Grigson work scarcely merits the designation "encyclopedia": apart from short introductory sections on national literatures and literary forms, it is "a volume of brief introductions to various writers who are worth reading" (Introd.). "Modern" is, in general, equated to "twentieth century" with emphasis on writers in English. The articles are not signed. Whereas the severe (and questionable) selectivity of the Grigson work allows treatment in some depth of chosen authors, the more generous policy of the Spender volume leads to inclusion of some author entries which provide little more than brief identification. The latter, however, emerges as a much more satisfactory reference tool: it covers the whole range of British and American poetry, with entries for general topics as well as for poets; most articles are signed with initials; omissions are much less obvious than in the Grigson work; and allotment of space seems generally sound.-E.S.

Kiell, Norman. Psychoanalysis, Psychology, and Literature: a Bibliography. Madison: Univ. of Wisconsin Press, 1963. 225p. \$5.

The relation between psychological theory and literature is an increasingly important subject, to which Mr. Kiell's work provides a needed key. Almost five thousand articles and monographs are included, from both primary and secondary sources, with no restriction as to school of thought. The aim was to secure as many items as possible from the 1900-1961 period, regardless of merit, although there is more scholarly than popular material. The editor makes no claim to exhaustiveness, and a spot check does reveal omissions. More serious failings are the lack of an author index (the material is arranged under fourteen broad headings), and the partial reliance of the subject index on title evidence alone. There are both a distressing number of typographical errors and an inconsistency in the translation of foreign language titles. The bibliography is welcome more as a pioneer effort than a definitive one, but it is nevertheless a valuable aid to an inadequately indexed field. -S.T. 
Line, Maurice B. A Bibliography of Russian Literature in English Translation to 1900 (Excluding Periodicals). London, Library Association, 1963. 74p. 24s. (Library Association Bibliographies, no.4).

The compiler has identified 426 items of nineteenth century translation into English from Russian literature, representing the work of forty-eight authors. Collections and anthologies are included, but not translations in periodicals. A chronological list of first appearances of translations in England or the United States supplements the main arrangement, alphabetical by author. There is also an index of translators. The work was planned to supplement Ettlinger and Gladstone's bibliography of English translations published between 1900 and 1945 (Guide R784), and the current annual, Index Translationum.-E.B.

Simmons, Merle Edwin. A Bibliography of the Romance and Related Forms in Spanish America. Bloomington: Indiana University Press, 1963. 396p. (Indiana University Folklore ser., 18) $\$ 4.50$.

Book and periodical studies of genuine Spanish-American folk ballads are listed here. Portuguese ballads and the works of "learned poets" (except for those of the colonial period) are not included. The author's policy, although selective, has been one of representative inclusion, so that the reader is at least directed to further sources if his special interest is not adequately covered here. All items which have been located and personally examined are annotated. Listings are based on geographical areas, usually identified by country. Each section is prefaced by a short essay on the general state of research and bibliographic control in that area, and there is an index of authors and titles.-E.A.

Smith, Gordon Ross. A Classified Shakespeare Bibliography, 1936-1958. University Park, Pa.: Pennsylvania State University Press, 1963.784 p. $\$ 37.50$.

Designed as a continuation of the Ebisch and Schücking bibliographies (Guide R436), this compilation is much less selective than those works, but without claim to comprehensiveness. It is "strictly speaking only a bibliography of everything on Shakespeare that has appeared in certain standard bibli- ographies, mostly annuals e.g., PMLA and Shakespeare Quarterly," (Foreword). In addition, many dissertation bibliographies have been gleaned for Shakespeare items, including any pre-1936 dissertations not in Ebisch and Schücking. The table of contents provides a detailed outline of the subject classes which are generally continued from Ebisch and Schücking, with some additions and amalgamations. Items are repeated in more than one class where appropriate but, regrettably, there is no index. On the whole, however, this represents the admirable execution of a formidable task.-E.S.

\section{BIOGRAPHY}

Who Was Who in America: Historical Volume 1607-1896. Chicago: Marquis, 1963. 672 p. $\$ 26$.

A supplementary volume to the Who Was Who in America set, this historical volume treats Americans and other significant figures in the early development of the country. As pointed out in the preface, the cutoff dates are not exact, and some persons deceased before 1607 and after 1896 are included. In the large reference collection the work will be useful mainly for quick reference since prominent careers are often reduced to lists of dates and offices held. Moreover, the majority of the 13,300 biographies are of United States congressmen, military and civil personnel who are covered in greater detail by other reference works. For the small library, however, and the home reference collection, the volume should be a welcome addition. The appended "Facts at your fingertips" section presents some useful lists of public officeholders and a chronology of major events.-E.Be.

\section{HISTORY}

Junod, Violaine I. and Resnick, Idrian N. The Handbook of Africa. New York: New York Univ. Press, 1963. 472p. \$10.

Designed to give a "factual picture" of African countries without editorial analysis or interpretation, this handbook indicates "basic source material by a thorough process of footnoting" (Introd.). Information which, with few exceptions, includes developments up to December 1961 is drawn from government documents, international organizations' publications, and standard nonofficial works. Arrangement is alphabetic by country, each 
section listing minimal information for geography, history, government, population breakdown, social data, and economy, with sources clearly indicated. The only map is that which appears on the endpapers.-R.K.

Repertorium fontium historiae medii aevi, primum ab Augusto Potthast digestum, nunc cura collegii historicorum e pluribus nationibus emendatum et auctum. Rome: apud Istituto Storico Italiano per il Medio Evo, 1962- . v.1- . (In progress?)

Contents: v.1, Series collectionum. 819p. 115,000 .

Planned by an international committee of medievalists, this first volume of a "new Potthast" (Guide V87) reveals the good judgment of the group and the careful editing of the compilers. In content it corresponds, generally, to the first major section, p.xxii-cxlvii, of the old work: i.e., an alphabetical listing of several hundred sets of chronicles, miscellanies, and other collections of medieval sources, together with their contents. Considerably expanded in size, it contains some sets omitted by Potthast and, of course, many published since the original work appeared, including a good representation of Byzantine, Arabic, Jewish, and Turkish materials not covered in Potthast. Bibliographic treatment of both series and individual titles is excellent-unfortunately not always the case in Potthast. Cross references are abundant, and rules of entry are carefully explained and illustrated (in Latin, as are the prefaces). Appended to the body of the work is an index of the collections by country or region.-J.N.W.

Sakamaki, Shunzo. Ryukyu: a Bibliographical Guide to Okinawan Studies, Surveying Important Primary Sources and Writings in Ryukyuan, Japanese, Chinese, and Korean. Honolulu: Univ. of Hawaii Press, 1963. 353p. $\$ 10$.

Noting the varied opportunities for research in Ryukyuan studies, the compiler has sought "to indicate the nature and scope of the literature on Ryukyu in East Asian languages, particularly in the fields of the social sciences and the humanities, from earliest times until the summer of 1961" (Pref.). Manuscript, book, and periodical materials are presented under broad topical headings, e.g., "Early Ryukyuan Source Material," "General Works on Ryukyu," "Ryukyuan Literary Arts," with numerous subdivisions for each. Much of the material is annotated. Authors and titles are given in transliteration in the bibliography, with oriental characters supplied in the indexes of titles of works, of authors, and of periodicals. Unfortunately, page references are provided only in the title index, and the table of contents provides the only subject index to the wealth of material in the bibliography.-E.S.

Shapiro, David. A Select Bibliography of Works in English on Russian History, 1801-1917. Oxford: Blackwell, 1962. 106p. $10 / 6$.

One aim of the compiler was "to furnish some notion of the present state of Western research on nineteenth and early twentieth century Russian history" (Pref.). American and English research is represented by the more substantial contributions in book and article form. Items are grouped under such headings as "General History," "Foreign Relations," "Economic History," with an index of authors and persons mentioned in the titles. There are references to reviews when the book is important or the title might be misleading, and some succinct comment by the author, a Research Fellow of Nuffield College, Oxford.-E.B.

West, John. Village Records. London: Macmillan; New York: St. Martin's Press, 1962. 208p. \$6.

"This book does not profess to be a complete outline of English local history, ... . but provides a series of practical exercises in documentary study" (Pref.). Documents are grouped in four historical periods, with a brief note on the political and social background; each type of document is introduced by a summary of its history and administrative origins, illustrated by a typical example, and followed by lists of suggested readings and of printed editions of texts and calendars. Although intended primarily for the beginning student or amateur historian having access to the documents and records described, this should nonetheless prove a useful handbook for students of English history and literature working abroad-both for the method of presentation and for the many bibliographical references.-E.S. 